A plaster-of-Paris cast was applied to the wrist and lower arm for a period of ten days, at the end of which time passive motion and massage were instituted, and a roller bandage substituted for the cast.

The patient was discharged on October 20 , and at the present time suffers from no disability.

The above case is recorded, not because of its importance from a clinical point of view, but because of its rarity and its absence from the surgical liternture. Doubtless, the fracture occurs with greater frequency than we might be led to believe, since absence of deformity and lack of definite symptomatology lead the attending physician to treat the injury as sprain rether than fracture.

178 State Strect.

\section{A DIAGRAM FOR TEACHING THE VARIETIES OF REGUILAR ASTIGMATISM}

Sidney L. Oisito, M.D., Pinlaielepiria

Instructor In Onhthnlmology, Jefrerson Medical College

With the accompanying dingram, I lave been able to make the subject of astigmatiom a litfle clearer to students. So far

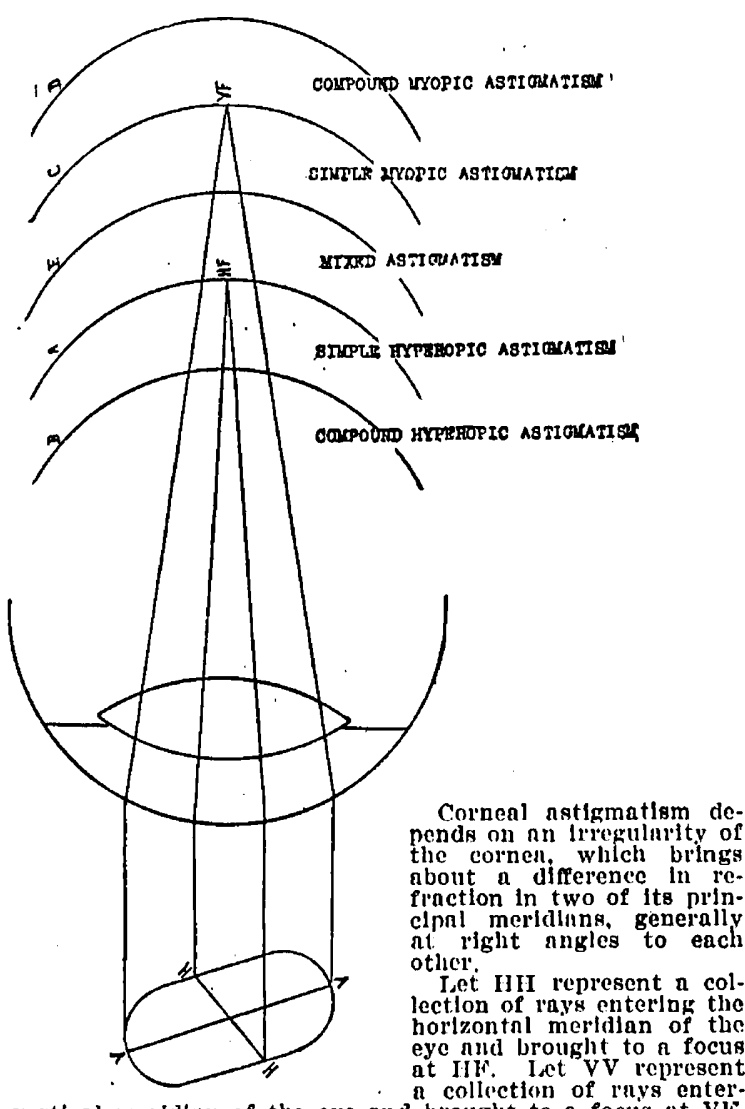

at rir. let veresent a colliction of roys enter Ing the vertfen merfalmo of the eye and brought to a focus at Observe the interval between these foch 'The kind of astigmnilsm I)'(enent may now be snld to depend on the length of the cycimiling of the cye (HII) emmetropte nnd ome merdalan (Vv) hyperople

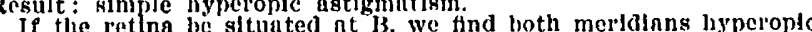
but the vertienl merldian (VV) inore so then the hortzontil merid.

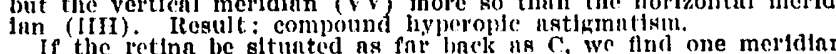

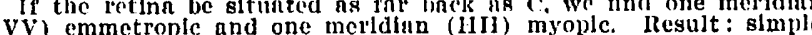
myopic astignitiam.

nyopic astlynisism. hut the borizontal merlition (IIII) move so thun the vertical merid lun (VV). Result: compound myople astlemallsm,

If the retina be situsted at we we flnd one merldinn (VV) byperoplc and one merldiun (IIII) myople. liesult : nixed astfgmatism.

I have not been able to find a like diagram in any text-book. The nearest approach to it is one by Br. Wolwarl Jackson. I ofler this with an elementary legend, which approaches the subject in a brief way.

1632 Walnut strect.

\section{Therapeutics}

\section{TRACHOMA}

This disease of the eyes is becoming of more and more importance as it becomes more and more widespread throughout our country. Therefore a brief summary of the elabornte presentation of the subject by Dr. Clarki of Evansville, Ind., will be valuable.

In 1897 the Secretary of the 'Treasury declared trachoma a dungerous contagious disense, and denied an immigrant afflicted with it entrance to this country, because of the discovery that the disease was being introduced and disseminated by jmmigrants. It seems to be undisputed that no comtry is free from the ravages of the disease, the history of which goes back to ancient times, and that no race is immume from it and no age exempt, except the very young. 1)r. Clark tells us that in young children the conjunctiva does not have sufficient adenoid tissue to give the disease an opportunity to develop.

1)r. Clark states that in spite of all the bacteriologie investigations, the enuse of trachomn is not yet known, the specific germ has not yet been discovered. It has been clearly shown, however, that in most cases of trachoma there is a mixer infection. The disease occurs in groups, in localities, in lrouses, in factories, and in schools, and is spread by contact or by contamination with articles like common towels, which are handled conjointly by the afflicted patient and his fellows.

The inflammation is locnted in the lymphoid tissue in the meshes of the connective tissue of the conjunctiva, and is "an cnormous lymphoid infiltration with cclls aggregating into masses, forming papillae, which, after receiving a vascular supply, degenerate, rupture and undergo cicatrization with the formation of the characteristic scar tissue of trachoma."

Clark belicves that a more or less acute inflammation always preceles this chronic process. The acute symptoms are "those of a severe conjunctivitis with lacrimation, photophobia, pain," and some swe!ling of the lids. He finds the ocular conjunctiva injected, and more or less chemosis present. The palpebral conjunctiva and the fornix are congested and turgid, and the follicles are swollen. Eversion of the lid causes pain. More or less purulent discharge develops and papillae form, varying in size, depending on the situation in the conjunctiva. The color of these papillac yaries according to the looseness of the conjunctiva, and they may amalgamate, forming masses or folds. The next stage, which occurs after a longer or shorter time, is that of scartissue formation; at this stage the secretion diminishes and the ocular congestion and photophobia cease. Still later the scar tissue begins to form in the region of the aggregations of the papillac, and with the progress toward cicatrization the so-called granulations of trachoma become separated into bands or islands, a very characteristic appearnece when the inflammation is well advancel toward spontuneous recovery. This scar tissue is less abundant in the lower than in the upper lid. lts formation soon causes a lagging of the lids on move. ment, and later may cause ptosis. 'The course of trachomn is chronic, and, although there mav be varying degrees of intensity of the inflammation and therefore a variation in the appearance of the conjunctiva, Clark believes that trachoma is always the same, and that to describe different types is only to cause confusion.

1. Clark. 'T.: 'Trachoma, with Especinl Roference to the stute of Mintersota, Jodinal-Lanest, March 15, 1013, p. 150. 